\title{
THE LATEST TRENDS IN THE CORPORATE SUSTAINABILITY AND ITS IMPLICATIONS FOR CZECH BUSINESSES
}

\section{Křečková Kroupová, Z.}

\begin{abstract}
This paper analyzes the state of corporate sustainability in the Czech Republic compared with world trends, including case studies of best practices. Corporate sustainability has developed from ad hoc activities dominantly focused on cost-cutting or corporate image improvements to strategic issue requiring the attention of corporate boards and top management. The development of sustainability as an integral part of corporate existence comprises of the following managerial implications: strategy, collaboration, and implementation. The strategic component requires mission reformulation, strategy redefinition and involves the board and top managers' broader thinking, leaders capable of open mindedness, and creativity. The collaborative component calls for intensive collaboration and communication with all stakeholders, including association with avant-garde partners, such as, NGOs, regulators, universities, and competitors. The implementation component addresses the need for high quality change management programs.
\end{abstract}

Keywords: Corporate sustainability; Czech Republic; Corporate social responsibility; shared value; strategy

JEL classification: M14, Q56

\section{Introduction}

In the article entitled "The Social Responsibility of Business Is to Increase Its Profits", published by the New York Times, Friedman (1970) labels social responsibility programs as "hypocritical window-dressing". However, today's global environment is different to that experienced by Friedman. Corporations, especially the multinational ones, are now predominant players in the world economy, given their financial power as well as their impact on employees, suppliers, consumers, and regulators. "In 1980, the world's largest 1,000 companies directly employed 21 million people, whereas in 2012 they employed seventythree million. In terms of market capitalization, in 1982 they totaled close to $\$ 900$ billion (\$2,4 trillion in 2012 dollars), or 33 percent of the world total, compared to a staggering \$28 trillion market capitalization or 50 percent of the world total in 2012" (UNEP, 2014, p. 8). Some multinational corporations are financially stronger than sovereign states as "out of 206 countries recognized by the United Nations, only 26 had nominal Gross Domestic Product (GDP) higher than the sales numbers reported by Royal Dutch Shell and Wal-Mart ( $\$ 454$ billion and $\$ 447$ billion, respectively) in 2011” (Serafeim, 2013).

However, the landscape in which they operate faces serious challenges such as, natural resource scarcity, growing demographics in developing countries and ageing of the population in developed ones, climate change, and poverty. As firms do not operate in isolation, especially multinational corporations (MNCs), they form part of a wider interconnected system that consists of society as a whole and the environment wherein 
these challenges are addressed. In addition, pressure from customers and employees must be taken into account. According to Němečková (2013, p. 373) “...just motivated and retained employees become one of the company's assets and a substantial point of difference from competition and they can be its competitive advantage". As a result, only motivated employees lead to satisfied customers. Zadražilová (2011, p. 125) states that "voluntary adoption of higher standards of social responsibility is a way to replace or postpone stricter legal regulations and possible creation of a competitive advantage". Therefore, MNCs that attempt to address these complexities no longer consider profit as their sole objective. Today, senior corporate leaders' decisions utilize more complex criteria - sustainability in all its dimensions, which comprise business, environment, and social aspects. This approach has developed over the past two decades.

The objective of this paper is to analyze the state of development of corporate sustainability in the Czech Republic compared with international trends.

Corporate sustainability activities of a company are important for all stakeholders. The progressive ones, from suppliers to customers, tend to select their partners based on their visible sustainability actions. Hence, the importance of sustainability increases for Czech entities as the country is a small export oriented open economy.

\section{Methods}

This paper is comprised of five parts that deal with international corporate sustainability trends. To further this study, it analyses two corporate case studies and the results that deliver managerial ramifications. To perform this task, general scientific methods such as analysis, comparison, induction and synthesis are used combined with case study research. The case study approach is primarily relevant as corporate sustainability is a complex issue for any business entity. Yin $(2003$, p. 2) states that "the case study method allows investigators to retain the holistic and meaningful characteristics of real-life events," such as complex organizational and managerial settings and processes that are subject to corporate sustainability.

\section{Corporate Sustainability}

Over the past two decades, views on corporate sustainability have transformed from the Brundtland Report on sustainability (WCED, 1987), Corporate Social Responsibility (CSR) to Shared Value (Porter and Kramer, 2011). Detailed definitions are provided in the appendix.

\subsection{International Corporate Sustainability Trends}

The "textbook" corporate sustainability approach of General Electric towards Ecomagination and Healthymagination (Luthans and Doh, 2012, p. 60-62), was, at origin, an exclusively business decision. "We did it from a business standpoint from Day 1," states Jeffrey R. Immelt, G.E.'s chief executive, "It was never about corporate social responsibility" (Lohr, 2011). The strategy to save energy comprehensibly matches the shared-value model, wherein 2013 GE revenues from Ecomagination products attained \$28B (GE Releases, 2014). 
In the late 1990s, the first sustainability efforts consisted of ad hoc or unsystematic activities and addressed cost-cutting. For example, these efforts consisted of energy savings, water savings, and waste minimization. Currently, companies focus more on a larger impact directly connected to specific corporate interests that address a wider collaboration with other entities. Filipová, Mokrejšová and Zeman summarized: „It is not only an academic issue or the problem of a distant future." (Filipová et al., 2014). Corporate sustainability developed from the former cost saving model to strategic collaboration and transformational initiatives that engage multiple corporate stakeholders.

According to the UN Global Compact, a long-time leader in sustainability issues, there are five actions to be taken by companies aiming to engage deeper in corporate sustainability: Principled Business, Strengthening Society, Leadership Commitment, Reporting Progress, and Local Action (UN Global Compact, 2014, p. 45). Principled business is reflected in respecting fundamental responsibilities in the areas of human rights, labor, environment and anticorruption; strengthening societies by supporting those around company; leadership commitment by sending strong signals though the organization that sustainability counts; reporting progress by transparency of business practices; and local action by viewing sustainability with a local lens even in distant supply chain locations. There were more than 8,000 companies and over 4,000 non-business entities that signed the UN Global Compact. Most business participants come from Europe (4,345 companies), followed by Latin America (1,712), Asia (1,267), and North America (364) (UN Global Compact, 2014, p. 46). There are 17 participants from the Czech Republic (UN Global Compact, 2015).

In 2014, the MIT and UN Global Compact global survey (Kiron et al., 2015) of more than 3,795 executives and managers from 113 countries revealed the key weakness of sustainability progress being the low involvement of corporate boards. This revelation significantly shifted the importance of sustainability as "the number of companies that have sustainability as a top management agenda item jumped from 46 per cent in 2010 to 65 per cent in $2014 "$ ".

Despite this, the survey indicates that only 22 percent of managers believe that their boards focus substantially on sustainability issues (Kiron et al., 2015). The integration of sustainability issues in the board committees' goals is of key importance. It demonstrates commitment and accountability. Sustainability requiring more complex approach might encounter a barrier at expertise at current composition of boards. For example, as companies are expanding globally, deep expertise in international markets is needed; however, the global board talent lags behind international revenues (Egon Zehnder, 2014, p. 13).

In terms of collaboration, 90 percent of them agree that companies have to collaborate to manage the sustainability challenges faced. However, only $47 \%$ of companies are engaged in sustainability-related partnerships (Kiron et al., 2015, p. 5).

\subsubsection{Sustainability at BASF Strategy}

In 2011, the multinational BASF redefined its strategy toward value creation through sustainability. This process included key decision makers' involvement, organizational repositioning of sustainability issues upwards to strategic levels, incorporating sustainability into the core competencies of each employee, product portfolio assessment, product sustainability benefits communication to customers, and redefinition of the corporate mission. 
In summary, BASF reformulated its mission to "...create chemistry for a sustainable future" (Post, 2014). The newly created corporate sustainability board included twelve company presidents. In addition, sustainability was moved from the environment, health and safety (EH\&S) department to strategic planning. "Sustainability has even made its way into the core competencies of every employee in the company. Today, one out of eight of the core competencies on every employee's performance review is called "driving sustainable solutions" (Post, 2014, p. 2). Furthermore, production was adjusted to harmonize with the sustainability mission. BASF's product portfolio was completely reassessed and "... placed each product into one of four categories: (1) accelerators, which are sustainability all-stars that make a significant contribution to the market; (2) performers, which meet basic market standards; (3) transitioners, which are actively addressing sustainability issues; and (4) challenged, which are products that have significant sustainability concerns for which action plans are being created" (Post, 2014, p. 2). This effort required change management to implement; "support for sustainability within the company has taken time, and moving a "tanker ship" of 112,000 employees is no small task" (Post, 2014, p. 3). However, all the effort delivered fruits in newly created portfolio of sustainability-centered products, sophisticated and clearly scientifically ahead of market regulations. These "accelerator" products in BASF's product portfolio generate for $\$ 10$ billion Euros, or almost $18 \%$ of the company's total annual sales (Post, 2014, p. 2).

\subsection{Czech Corporate Sustainability Trends}

Assuming that the best companies in the field of corporate sustainability participate in the most important competitions, we can say that the winners of these competitions are those that indicate the trends.

As an EU Member, the Czech Republic is primarily benchmarked with other member states and participates at joint European activities. European institutions support the sustainability approach by a thorough awareness of best practices. To support sustainability, the European Commission organized the first European CSR Award Scheme. In the 2012/2013 timeframe, the nomination committee received 749 applications, 259 from SME and 490 from the larger company category. The objective of the European CSR Award Scheme is to afford visibility to excellence in practice and to share best practices across the EU, and in doing so, to encourage enterprises to adopt successful examples and cooperate with stakeholders to facilitate socially responsible commitments.

The European CSR Award scheme is based on a series of national CSR award schemes in EU member states and other European countries (European Commission, 2014 , p. 2). The key criterion of a successful project is partnership that couples at least one business and one non-business partner. Another criterion is that the project has to qualify for the theme 'Corporate Social Responsibility: Partnership, Innovation and Impact' (European Commission, 2014, p. 7) Projects are evaluated by a jury that comprises diverse stakeholders. Jury members select projects based on the positive impact their partnership contributes to both society and business. Judges are interested in innovative and sustainable initiatives that can be replicated effectively (European Commission, 2014, p. 7) As the National Award is offered in two categories, there are two divisions: partnerships that involve small and medium-sized enterprises (SMEs) and partnerships with larger companies. 
Thirty-four companies with 41 CSR projects participated and reflected the social agenda prevalent in the Czech Republic. The 2012/2013 winner in the SME category is the construction company PRVNII CHODSKÁ s.r.o. with the project "Endowment Fund Stairs into the Life" that addresses CSR issues in the areas of employment, community impact, engagement, and education. The winner in the large company category was the consulting company Accenture with their project entitled "Accenture Academy" that addresses employment, training and education (European Commission, 2014).

In the Czech Republic, for more than a decade, development of corporate social responsibility has progressed. Through the auspices of various awards such as TOP Responsible Company (TOP Odpovédná firma), Socially Responsible Company (Společensky odpovědná firma), Socially Responsible Entrepreneur of the Year (Sociálně prospěšný podnikatel roku), to name a few, these annual awards honor those engaged in exemplary CSR. These awards vary in terms of their impact and respect gained by the business community, media and general public. One of the most valued is the organization "Business for Society" (Byznys pro společnost) which is also a national partner of the previously mentioned European CSR Award Scheme.

Reflective of the evolution of Czech CSR trends, the nature and significance of the awards has transformed proportionally to the expansion of the corporate mindset and focus on social responsibility. While in 2010, one of the most prominent awards was TOP Philanthropy (Top Filantrop), as of 2011, the most prestigious category is currently, TOP Responsible Company (TOP Odpovédná firma). According to detailed reports of eighty award evaluators "the strategic approach of the major 50 large corporations improved by 20 percent toward responsible and sustainable way of doing business" (Kalousová, 2014). Increasingly companies focus their sustainability efforts in areas associated with their core business. IBM, the 2014 winner, was awarded for innovation and the strategic concept of job-inclusion of disadvantaged groups. The winner of the category "TOP Responsible Small Enterprise" ZLKL, s.r.o., was awarded for the responsible corporate management and organizational culture. A record number of 101 companies participated (topodpovednafirma.cz, 2014). Judges comprised an expert panel that consisted of representatives from the commercial and non-business sector, state administration, experts and respected personalities that actively participate in responsible business development in the country. They seek companies that are unique in their domain and contribute best practices of responsible and sustainable ways of doing business.

Not until 2014 did Czech state bodies enter into the CSR discussion with the government's introduction of the National Action Plan for Corporate Social Responsibility (Kourili, 2014).The National Award of the Czech Republic for Socially Responsible Company, being awarded by the Česká společnost pro jakost, is part of the plan. The basis of the award is the Czech method KORP, know-how Rady kvality ČR that borrows from the GRI, EFQM model and CAF. The KORP method comprises both internal selfassessment and external assessment. Detailed guidelines are provided along assessing numerous criteria.

In 2014, the winners were the companies DIAMO, in the industry category, and ROSSMANN, in retail, for their exemplary relationship with society and their approach toward sustainable development (Kouřil, 2014). 


\subsubsection{CISCO Network Academy}

A pertinent example of sustainability implementation is the CISCO Network Academy, with its specific mission and impact in the Czech Republic.

With an emphasis on outreach to underserved communities, CISCO in 1997 launched the Cisco Networking Academy, a training initiative to enhance knowledge in the latest global networking technologies. Since the project's start, Cisco has trained more than four million students through the creation of ten thousand academies in 165 countries. Seventy percent of the program's graduates have attained new or improved jobs, increased responsibilities or a higher salary (Bockstette and Stamp, 2011). An investment of $\$ 350$ million USD strengthens Cisco's business through the creation of a pool of qualified technicians able to administer complex networks. It also creates and further educates sophisticated customers in high-growth markets. "It is a textbook example of how to build long-term competitive advantage via a sophisticated social engagement program" (Bockstette and Stamp, 2011).

In addition, specific to the Czech Republic, Cisco specialists participated in curriculum reform of the educational system, a major change since 1989. Through their assistance, they defined information technology-related standards for the educational program framework. In doing so, CISCO strategically influenced the development of the national educational system. It is an exemplary case, when a corporate expertise can bring value to a whole country's education. (Bockstette and Stamp, 2012).

To conclude the topic, the approach towards sustainability is transforming from pure philanthropy through individual CSR programs, supervised by separate departments in corporations, to sustainability as an integral part of corporate strategy.

It may be stated that the situation in the Czech Republic appears to be on a good track. Also, there are several role models that serve as inspiration for others. It is difficult to evaluate whether the existence of the two awards, TOP Responsible Company and the National Award of the Czech Republic for the Socially Responsible Company, are beneficial to inspire participants to actively participate or whether it dilutes the intended purpose of sustainability on a national level.

\section{Managerial Implications}

Sustainability as an integral part of corporate existence entails the following managerial implications:

1. Strategic: strategy reformulation, mission revision and possibly reformulation, an intense involvement of the board and top managers, leaders with broader thinking, open mindedness, and creativity. It involves integrating corporate sustainability into the duties of the board members, and reconsidering composition of the board and top management team in terms of cultural, gender, age, study and work experience diversity so that to reflect new strategy focus.

2. Collaborative: intensive collaboration and communication with all stakeholders, including collaboration with new and unique partners, such as, NGOs, regulators, universities, competitors, both locally and globally across the whole value chain. 
3. Implementation: application of sustainability into all functional aspects of the organization requires both tangible and intangible changes. Both represent challenges, entail time and resources and require good quality change management programs to be successful.

\section{Future Research}

Future research consists largely of the analysis and comparison of Czech corporate sustainability efforts based on ownership types and industry. In addition, the comparison of trend development in the Czech Republic and its larger trading partners is of interest.

Lastly, as to Friedman's claim that social responsibility programs are "hypocritical window-dressing". He would be astonished to read how the CEO of Apple, Tim Cook, explained to shareholders his perspective of spending in socially responsible areas, "If you want me to do things only for ROI reasons, you should get out of this stock" (Denning, 2014).

\section{Appendix - Corporate Sustainability and Related Terms}

Sustainable development, first defined in the Brundtland Report, "is the development that meets the needs of the present without compromising the ability of future generations to meet their own needs" (WCED, 1987).

Corporate Social Responsibility (CSR) "a concept whereby companies integrate social and environmental concerns in their business operations and in their interaction with their stakeholders on a voluntary basis" (European Commission, 2002, p. 3).

(Corporate) Sustainability is a way of business based on the Corporate Shared Value (CSV) between the company and its environment. The term Sustainability, often exchanged with CSR, is more complex as it reflects new management of the company based on strategy focused on long-term profit creation as well as addressing social, environmental and ethical challenges.

Porter and Kramer define Shared Value as "policies and operating principles that enhance the competitiveness of a company while simultaneously advancing the economic and social conditions in the communities in which it operates" (Porter and Kramer, 2011). Shared value aims to "a more sophisticated form of capitalism," in which "the ability to address societal issues is integral to profit maximization instead of treated as outside the profit model" (Porter and Kramer, 2011).

\section{References}

Bockstette, V., \& Stamp, M. (2011). Creating Shared Value: A How-to Guide for the New Corporate (R)evolution. Retrieved June 20, from http://www.fsg.org.

Bockstette, V., \& Stamp, M. (2012). Vytváření sdílené hodnoty, Průvodce firemní (r)evolucí. Prague: FSG.

Denning, S. (2014). Why Tim Cook Doesn't Care About, The Bloody ROI'. Retrieved February 21, 2015 from http://www.forbes.com/sites/stevedenning/2014/03/07/ why-tim-cook-doesnt-care-about-the-bloody-roi/.

Egon Zehnder (2014). Achieving Global Board Capability: Keeping pace with global opportunity. Egon Zehnder Global Board Index 2014. Retrieved May 25, 2015 from http://www. egonzehnder.com/global-board-index-2014. 
European Commission (2002). Communication from the commission concerning corporate social responsibility: a business contribution to sustainable development. Commission of the European Communities.

European Commission (2014). First European CSR Awards Projects 2013. Golden Book. Retrieved February 21, 2015 from www.europeancsrawards.eu.

Filipová, A., Mokrejšová, V., \& Zeman, J. (2014). Social Responsibility and Food Waste in the Czech Republic. E-Leader International Journal, 9(2).

Friedman, M. (1970). The Social Responsibility of Business Is to Increase Its Profits. The New York Times. Retrieved February 21, 2015 from http://query.nytimes.com/mem/archive-free/ pdf?res=9E05E0DA153CE531A15750C1A96F9C946190D6CF.

GE Releases (2014). GE Releases 2013 Progress against Sustainability Commitments. Retrieved February 21, 2015 from http://www.businesswire.com/news/home/20140630006140/en/ GE-Releases-2013-Progress-Sustainability-Commitments\#.VOowlBt0zzU.

Kalousová, P. (2014). Prestižní cenu za odpovědné podnikání získaly IBM a ZLKL. Retrieved February 21, 2015 from http://www.topodpovednafirma.cz/tiskova-zprava.html.

Kouřil, T. (2014). Nejlepší firmy a organizace dnes večer převezmou ocenění "Excelentní firma" a "Společensky odpovědná firma". Retrieved February 21, 2015 from http://www.narodnicena.cz/clanky/ aktualne-cz-11-2014-nejlepsi-firmy-a-organizace-ziskaly-prestizni-narodni-ceny.

Kiron, D. et al. (2015). Joining Forces: Collaboration and Leadership for Sustainability. MIT Sloan Management Review. Retrieved June 1, 2015 from http://sloanreview.mit.edu/projects/ joining-forces/.

Lohr, S. (2011). First, Make Money. Also, Do Good. New York Times. February 21, 2015 from http:// www.nytimes.com/2011/08/14/business/shared-value-gains-in-corporate-responsibilityefforts.html.

Luthans, F., \& Doh, J. P. (2012). International Management. Culture, strategy, and Behavior. New York: McGraw-Hill.

Němečková, I. (2013). The Role of Salary in Employee Motivation and Retention in the Financial Sector of the Czech Republic in Relation to Herzberg's Two Factor Theory of Work Motivation. Politická ekonomie, 61(3), 373-392.

Porter, M. E., \& Kramer, M. R. (2011). Creating shared value. Harvard business review, 89(1/2), 62-77.

Post, R. (2014). For BASF, Sustainability Is a Catalyst. MIT Sloan Management Review Blog. Retrieved February 21, 2015 from http://sloanreview.mit.edu/article/ for-basf-sustainability-is-a-catalyst/.

Serafeim, G. (2013). The Role of Corporation in Society: An Alternative View and Opportunities for Future Research. Harvard Business School Working Paper.

topodpovednafirma.cz (2014). TOP odpovědná firma. Cena byznysu pro společnost, 2014. Retrieved February 21, 2015 from http://www.topodpovednafirma.cz/finaliste-a-oceneni.html.

UNEP (2014). Integrated Governance. A New Model of Governance for Sustainability. United Nations Environment Programme. Retrieved June 1, 2015 from http://www.unepfi.org/fileadmin/ documents/UNEPFI_IntegratedGovernance.pdf.

UN Global Compact (2014). Guide to Corporate Sustainability. Shaping Sustainable Future. Retrieved June 1, 2015 from http://www.unglobalcompact.org/docs/publications/UN_ Global_Compact_Guide_to_Corporate_Sustainability.pdf. 
UN Global Compact (2015). Participants and Stakeholders. Retrieved May 25, 2015 from http:// www.unglobalcompact.org.

WCED (World Commission on Environment and Development) (1987). Our Common Future. Oxford: Oxford University Press.

Yin, R. K. (2003). Case Study Research:Design and Methods. Thousand Oaks: Sage.

Zadražilová, D. et al. (2011). Udržitelné podnikání. Prague: Oeconomica Publishing House.

\section{Author}

\section{Ing. Zuzana Křečková Kroupová, M.A., Ph.D.}

Assistant Professor

Department of Retailing and Commercial Communications

Faculty of International Relations

W. Churchill sq. 4, 13067 Prague 3, Czech Republic

zuzana.kreckova@vse.cz

The author wishes to express gratitude to Dr. Richard Brunet-Thornton for his on-going consultation in the preparation of this manuscript. 